あ大きく䘽祭される傾向があるう，以上和よびその他の理

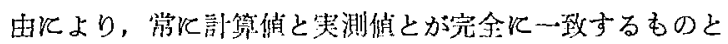
はいえないが, 平均して約15\%程度大きい值が綜合衝撃储 として知られたので，綜合衙慗法の有用性む明らかてなっ

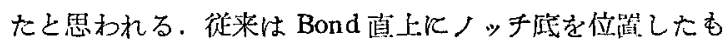
のについてのみ述へて来たが, Bond から若干離れた所飞 ついても同様浪成立つことが知られたようである。

\section{8 結言}

本実験により，鎆材の王延異方性ならびに履歴が熔接部 近傍の獬化領域，衙揧値分们飞対して相当異なるようすを 与光，また試駼片の採取法によって若干異なることが知

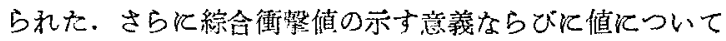
の俨洒も招こなった．これらの結果から次の上うな結論が 渞かれるであるう：

1）鋼板のI延異方性は静的引張試娩ではあまり明瞭に 知るととは四難である。

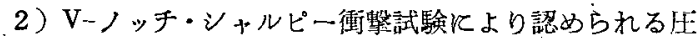
延鐝板の異方性は完全烧鈍後もほとんぞ変化しない．

3）熔接熱影響部最高硬度の鋼板履歴化よる差は極めて 僅かである。

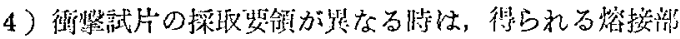

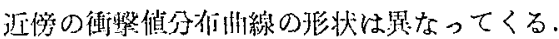

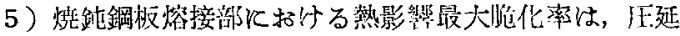

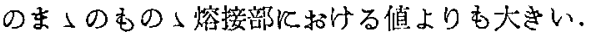

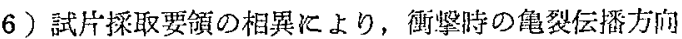
が鋼板压延方向飞平行であっても，あるいは垂成であって

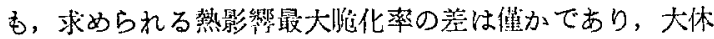
同程度となる。

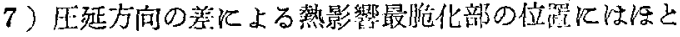
んど差がない。

8）実测される綜合衙撃值は, 通常法により求めた衙撃 䛧分布飞基ずく計算值よりも $0 \sim 23 \%$ ，平坂して約15\%程 度大きい。

本実験遂行にあたり終始御指導を戴いた永井部長ならび に末光課長に深謝を捧げる次第である。

\section{文献}

1) 応和：蓺影響部の脆化飞ついて(第 1 8 報), 熔接 学会誌. Vol. 23. No. 1/2 以降.

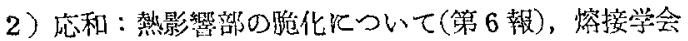
誌。投稿ずみ。

\title{
造船用厚銅板の板厚勃果に關するニ三の頞驗*
}

\author{
吉田俊夫林 松永和介** 寺井 清林 金谷文善林
}

\section{Some Investigation for the Effect Increasing Thickness of Ship Steel Plate*}

By T. Yoshida**, W. Matsunaga**, K. Terai** and F. Kanaya**

\begin{abstract}
Authors have made a study of the effect of the thicker plates urged by the need to solve the following constructional problem of 45,000 DWT ore and oil carrier which our yard is planning of build.

The construction of this ship as it is shown in the Fig. 1-Midship section, there is a large opening in the centre of upper deck. In this case, in way of supporting upper deck sectional area, there arose a question whether we shall adopt the doubling system which is usually applied to ore carrier, or boldly do away with the doubling plate and use extra thick plate instead. To be more in detail, if (a) two lines of doubling plates were passed on one side the plate thickness of upper deck would be sufficient by being $38 \mathrm{~mm}$, but if (b) the doubling plates were limited to a single line then the thickness of plates requires to be $40 \mathrm{~mm}$ and in case of (c) no doubler the thickness must be $47 \mathrm{~mm}$.

In consideration of the work in the spot, the compensation by the doubling involves a diffecult job. On the other hand, in consideration of the quality of steel and its weldability it seems more undesirable as the thickness of the steel plates become larger. As far as the thickness of the plates is concerned, there is not much difference in the effect between $38 \mathrm{~mm}$ and $40 \mathrm{~mm}$, so our consideration of the problem was focussed to whick should we choose, (b) or (c).
\end{abstract}

* 原稿受付 昭和30年12月27日（昭和30年度熔接学会秋季学術䛾演会に和いて発表）

** 正貝 川䐀重工業株式会社 Member, Kawasaki Dockyard Shipbuilding Dept., Hull Section. 
The steel to be used for the purpose which came to our mind was $C$ class steel of $A B$ Rule, but when the thickness of steel becomes so large it is questionable whether we many obtain a suitable material that comes within the specifications of $\mathrm{C}$ class steel and a satisfactory joinability of the same time. So with a view to find out which possesses better joinability and the weldability for service, we made the following tests in order to make a comparative study between (b) and (c).

1. Tension Test in room temperature.

2. Standard V.Charpy Impact Test in the range of temperature $-40^{\circ} \mathrm{C}$ to $+60^{\circ} \mathrm{C}$.

3. Longitudinal Bead Bending Test (Kommerell Test) in the rang of temperature $-60^{\circ} \mathrm{C}$ to $+40^{\circ} \mathrm{C}$. From these tests we could reach to the following conclusions.

(1) According to the static tension test of both plates, of cf.Fig. 4, the normalizing will increase both yield strength and elongation, but gives hardly any effect to the tensile strength. (cf Fig. 5)

(2) In the V-Charpy test, cf Fig. 6, the normalizing will lower $40 \mathrm{ft}-1 \mathrm{~b}$ transition temperature of the steel of both plates, but there was not hardly notceable of the effect to 15 ft-1b transition temperature. (cf Fig. 9) Gerierally $47 \mathrm{~mm}$ thick plates, in comparison with $40 \mathrm{~mm}$ thick plates, the notch sensitivity is somewhat larger, but the impact value in low temperature was sufficiently large when normalized. (cf Table 3 and Figs 7-13)

(3) In the Kommerell test, cf Figs 14 and 27, both plates showed much larger bending angle than what is required under Austrian Welding Standard (cf Fig. 27). (cf Fig. 28). When low hydrogen electrode was used, the toughness of the weldments was very high, and even when the other types of electrode were used, if weldment was preheated it regained its toughness very noticeably. (cf Figs. 22-26)

\section{1 緒言}

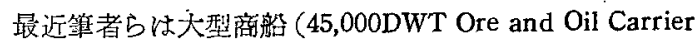
）を建造するに際し，上甲板用䤵材について後述の如き構 造上の問題から，板厚 $40 \mathrm{~mm}$ と $47 \mathrm{~mm}$ の造船用鋼材を比 較する必要に迫られた。現在までのところこの範团の板厚 の鋼板が㷷接船体構造に使用された例は極めて稀であって そのためこの雨者の一主として熔接性という観点から眺 めた一一材質の比较隹与する筫料は非常に少ない，そこ でこの点を調查し，かつ今後の参考供すへく，同一キャ 一シの銅塊より压延せる 2 種の鋼板につき一連の諸実娩を 䘕い結困をまとめたので，こ」に報告する次第である。

\section{2 実験を行つた理由}

さて D.W. 45,000 噸型商船（当社第951号船）の設計に 祭し，問題となっった諸点は次の通りである。すなわちFig.

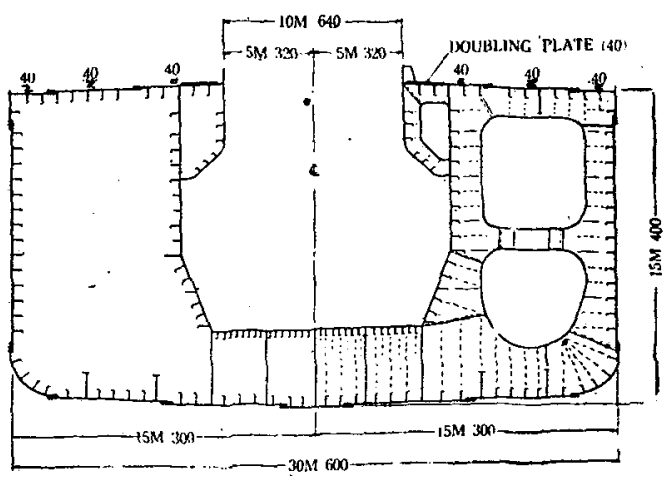

Fig. 1 Midship section of 45,000 DWT ore and. oil cbrrier
1てみられる如く，上記船体構造に和いては上甲板の和央 部に巾約 $10 \mathrm{~m} の$ 開口部があり，このため雨舫の甲板の断面 積は過大なるものが要求される結果となる. 現在では板厚 の增加山鋼材の使用性能を阻害するという考兑から，加よ

DECK PL 38 WITH 38 DOURLING PLAIE.

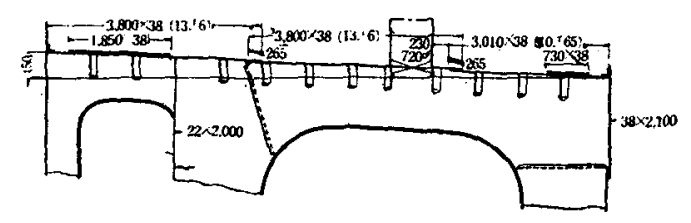

DECK PL \pm 0 WITH 90 DOUBLING PLATE

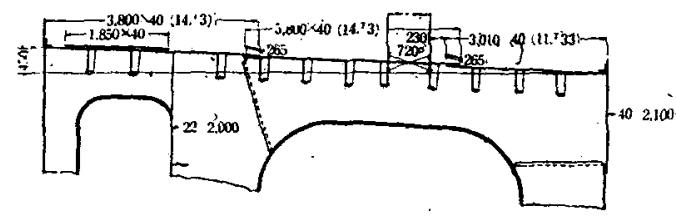

DECK PL. 47 WITH NO DOUBLER

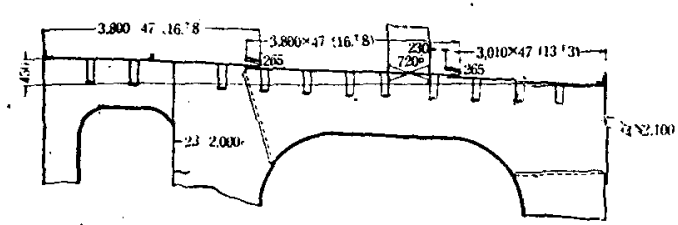

Fig. 2 Comparison of upper deck construction with different thickness of steel plates 
うな場合には doubling plate を設けて断面積を增加して いるが,この doubling system は工作上非常に面倒なも のであり, 工期の短縮化を要求せられる現造船界の意図と 相反する性質のものでああるので，でき得ればこれの採用 は廃したいというのが吾人の希望とするととろである。こ の doubling system と板厚の関係は三者 飞分かれ次の条件となっている.すなわち これらは Fig. 2 にみられる如く，

(a) doubling plate を片舷に 2 条通せ

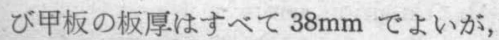

(b) doubling plate を1条にすれば $40 \mathrm{~mm}$.

(c) no doubler とすれば $47 \mathrm{~mm}$ となる. この中 $38 \mathrm{~mm}$ と $40 \mathrm{~mm}$ とでは板厚の差 とよる影響は少ないと思われるので, 従っ て問題の焦点は上記 (b)(c)のいずれを巽 ぶかにある訳であり，この両者についてそ の材質を詳細に吟味した上，これらの差が 許容範囲にあれば(c)を採用すべく本実験 を行った訳である.

\section{3 使 用 鋼 材}

使用せる鋼材は日本製鋼所室蘭製作所に て製鋼圧延せるむのであるが，これの使用 せる ingot 仿い゙れす $70 \mathrm{~T}$ 塩基性平捠飞
よる同一 charge のものより鋳込み, 同所の 3 万馬力 4 段 式大型压延機によりそれぞれ $2 \mathrm{M} \times 4 \mathrm{M}$ ならびマ $2 \mathrm{M} \times 9 \mathrm{M}$ の寸法に分け，後者については焼準 $900^{\circ} \mathrm{C} 2 \sim 3$ 時間を行 った.

これら鋼材の化学成分, 機械的性質ならびそ粒度は,

Table 1 Steel Tested

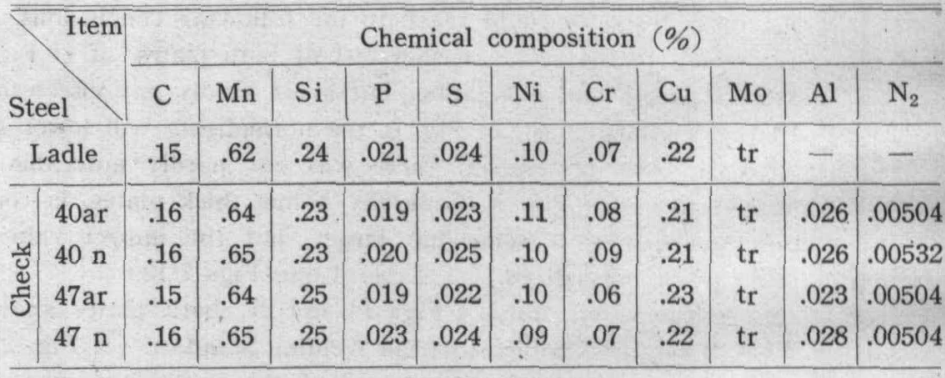

\begin{tabular}{|c|c|c|c|c|c|c|c|c|}
\hline \multirow[t]{3}{*}{ Item } & \multirow{2}{*}{\multicolumn{3}{|c|}{$\begin{array}{l}\text { Maecnical } \\
\text { Longitudinal }\end{array}$}} & \multirow{2}{*}{\multicolumn{3}{|c|}{$\begin{array}{c}\text { properties } \\
\text { tratsvers }\end{array}$}} & \multirow{2}{*}{\multicolumn{2}{|c|}{$\begin{array}{r}\text { Grain size } \\
(\text { a.s.t'm. })\end{array}$}} \\
\hline & & & & & & & & \\
\hline & $\begin{array}{l}\text { Y.P. } \\
\left.\mathrm{kg} / \mathrm{mm}^{2}\right)\end{array}$ & $\begin{array}{c}\text { T.S. } \\
\left(\mathrm{kg} / \mathrm{mm}^{2}\right)\end{array}$ & $\mid \begin{array}{c}E \\
(\%)\end{array}$ & $\begin{array}{c}\text { Y.P. } \\
\left(\mathrm{kg} / \mathrm{mm}^{2}\right.\end{array}$ & $\begin{array}{c}\text { T.S. } \\
\left(\mathrm{kg} / \mathrm{mm}^{2}\right)\end{array}$ & $\begin{array}{l}E \\
(\%)\end{array}$ & $\begin{array}{c}\text { Auste- } \\
\text { nite }\end{array}$ & $\begin{array}{l}\text { Ferr- } \\
\text { ite }\end{array}$ \\
\hline 40ar & 27.4 & 43.9 & 32.0 & 27.0 & 43.6 & 30.7 & 7 & 7 \\
\hline $40 n$ & 26.6 & 43.4 & 32.0 & 27.3 & 42.2 & 32.0 & 7 & 8 \\
\hline $47 \mathrm{ar}$ & 26.4 & 45.0 & 31.0 & 26.0 & 43.9 & 28.2 & 7 & 7 \\
\hline $47 \mathrm{n}$ & 27.7 & 43.3 & 30.7 & 26.5 & 42.7 & 32.0 & 7 & 8 \\
\hline
\end{tabular}

40,47 : plate thickness in $\mathrm{mm}$ ar: as rolled condition n : normalized condition
AS ROLLED CONDITION
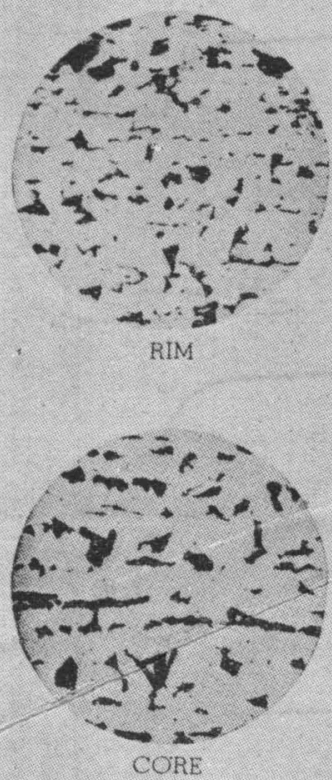

THICKNESS : $40 \mathrm{MM}$
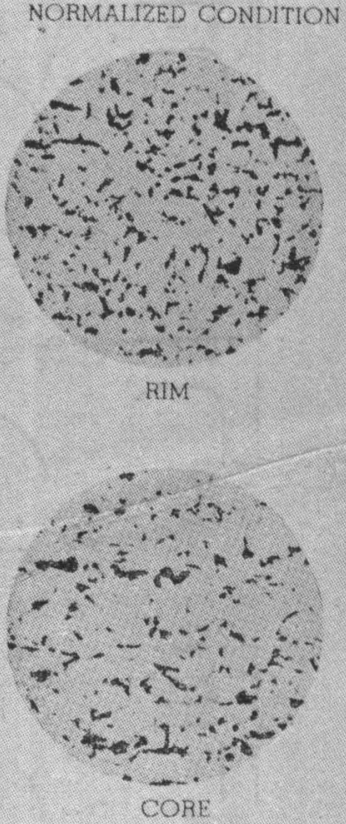

Fig. 3 Microstructures of steels tested

THICKNESS : 47MM

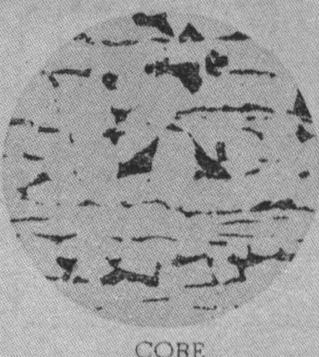

NORMALIZED CONDITION
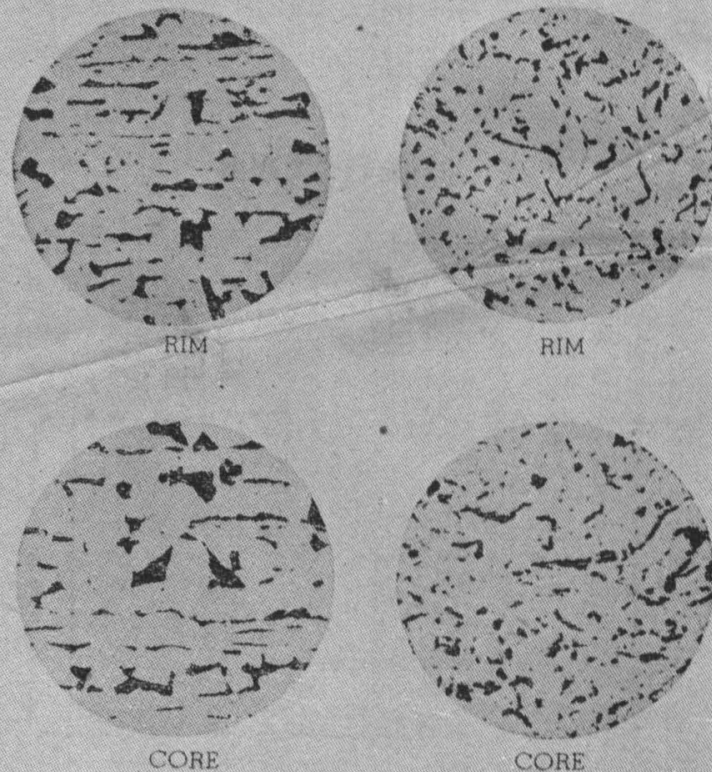

CORE

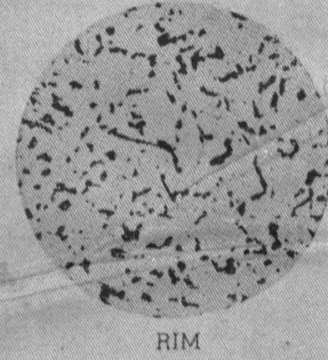


Table 1 に录す通りで, 製作目標は ABS のC級鎆とした。 (ABSならびK Lloyd の両船級協会ではこの範国の板曆

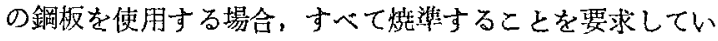
る）な特 Fig. 3 Kはフエライトならびれオーステナイト 粒度測定のための顕微鏡写真を示す。
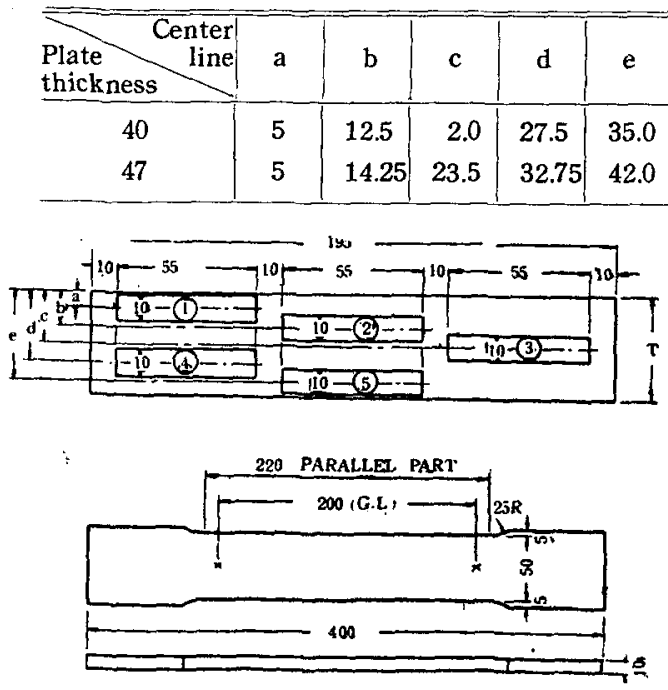

Fig. 4 Position of tension specimen and its detail
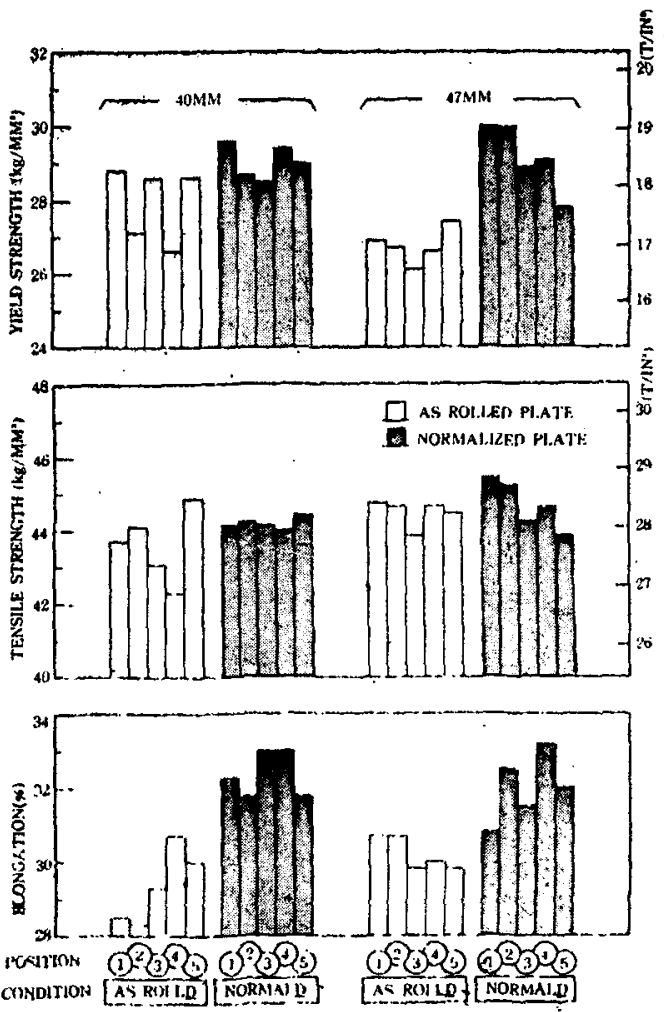

Fig. 5 Result of tension test for as rolled and normalized plates $40 \mathrm{~mm}$ and $47 \mathrm{~mm}$ thick (specimens were taken paralell to rolling direction)

\section{4 引張試験について}

\section{(4.1) 引誩試験片採取琵領}

本試験は板厚 $40 \mathrm{~mm}$ ならびK $47 \mathrm{~mm}$ のそれぞれ王延の

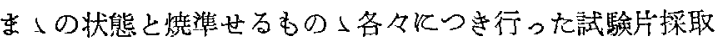

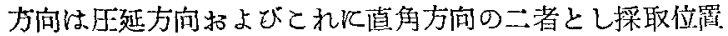
はFig.4にみられるように板厚方向に5種とし，これによ り鋼板の rim 部と core 部の美を測定した。

\section{(4.2) 引张武験結罢}

陚験は各ンリーズごとに 3 本宛行い，これより降代点， 抗镸力, 降伏比, 延伸率 (G.L. $=200 \mathrm{~mm}$ ) を測定した. こ の結果を Table 2 に示守.

(4.3) 荐 察

Table 2 の結果からみて板厚 $40 \mathrm{~mm}$ と $47 \mathrm{~mm}$ の鋼板間の

Table 2 Results of Tension Test

\begin{tabular}{|c|c|c|c|c|c|c|c|}
\hline $\begin{array}{l}\text { Thickn- } \\
\text { ess } \\
\text { (mm) }\end{array}$ & $\begin{array}{l}\text { Condis- } \\
\text { ion }\end{array}$ & $\begin{array}{l}\text { Direct- } \\
\text { ion }\end{array}$ & $\begin{array}{l}\text { Posis- } \\
\text { ion }\end{array}$ & $\begin{array}{l}\text { Yield } \mathrm{Pt} . \\
(\mathrm{kg} / \\
\left.\mathrm{mm}^{2}\right)\end{array}$ & $\mid \begin{array}{c}\text { Tensile } \\
\text { Strength } \\
(\mathrm{kg} / \\
\left.\mathrm{mm}^{2}\right)\end{array}$ & $\begin{array}{l}\text { Yield } \\
\text { Ratio } \\
(\%)\end{array}$ & $\begin{array}{c}\text { Elonga- } \\
\text { tion } \\
(\%)\end{array}$ \\
\hline 40 & $\stackrel{\text { as }}{\text { rolled }}$ & longl & $\begin{array}{l}1 \\
2 \\
3 \\
4 \\
5\end{array}$ & $\begin{array}{l}28.8 \\
27.1 \\
28.6 \\
26.6 \\
28.6\end{array}$ & $\begin{array}{l}43.7 \\
44.1 \\
43.1 \\
42.3 \\
44.9\end{array}$ & $\begin{array}{l}65.9 \\
61.2 \\
66.3 \\
62.8 \\
63.7\end{array}$ & $\begin{array}{l}28.5 \\
28.3 \\
29.3 \\
30.7 \\
30.3\end{array}$ \\
\hline 40 & $\begin{array}{l}\text { as } \\
\text { rolled }\end{array}$ & trans & $\begin{array}{l}1 \\
2 \\
3 \\
4 \\
5\end{array}$ & $\begin{array}{l}28.2 \\
26.4 \\
27.5 \\
26.6 \\
27.6\end{array}$ & $\begin{array}{l}44.0 \\
42.7 \\
42.0 \\
42.5 \\
44.1\end{array}$ & $\begin{array}{l}64.1 \\
61.9 \\
65.4 \\
62.4 \\
62.3\end{array}$ & $\begin{array}{l}29.8 \\
29.5 \\
31.2 \\
31.0 \\
29.7\end{array}$ \\
\hline 40 & $\begin{array}{l}\text { normal- } \\
\text { ized }\end{array}$ & longl & $\begin{array}{l}1 \\
2 \\
3 \\
4 \\
5\end{array}$ & $\begin{array}{l}29.4 \\
28.6 \\
28.5 \\
29.4 \\
29.0\end{array}$ & $\begin{array}{l}44.4 \\
44.2 \\
44.2 \\
44.2 \\
44.5\end{array}$ & $\begin{array}{l}66.8 \\
64.8 \\
64.5 \\
66.5 \\
65.2\end{array}$ & $\begin{array}{l}32.3 \\
31.8 \\
33.0 \\
33.0 \\
31.8\end{array}$ \\
\hline 40 & $\begin{array}{l}\text { normal- } \\
\text { ized }\end{array}$ & trans & $\begin{array}{l}1 \\
2 \\
3 \\
4 \\
5\end{array}$ & $\begin{array}{l}28.8 \\
29.3 \\
28.7 \\
29.0 \\
30.8\end{array}$ & $\begin{array}{l}44.5 \\
44.2 \\
43.4 \\
43.8 \\
45.0\end{array}$ & $\begin{array}{l}64.7 \\
65.8 \\
66.1 \\
66.1 \\
68.5\end{array}$ & $\begin{array}{l}31.0 \\
32.7 \\
33.0 \\
32.8 \\
31.6\end{array}$ \\
\hline 47 & $\begin{array}{l}\text { as } \\
\text { rolled }\end{array}$ & longl & $\begin{array}{l}1 \\
2 \\
3 \\
4 \\
5\end{array}$ & $\begin{array}{l}26.9 \\
26.7 \\
26.1 \\
26.6 \\
27.4\end{array}$ & $\begin{array}{l}44.8 \\
44.7 \\
43.9 \\
44.7 \\
44.5\end{array}$ & $\begin{array}{l}60.2 \\
59.8 \\
59.3 \\
59.4 \\
61.6\end{array}$ & $\begin{array}{l}30.7 \\
30.7 \\
29.8 \\
30.0 \\
29.8\end{array}$ \\
\hline 47 & $\begin{array}{l}\text { as } \\
\text { rolled }\end{array}$ & trans & $\begin{array}{l}1 \\
2 \\
3 \\
4 \\
5\end{array}$ & $\begin{array}{l}25.9 \\
26.5 \\
25.1 \\
26.6 \\
26.4\end{array}$ & $\begin{array}{l}44.6 \\
43.9 \\
43.0 \\
44.0 \\
44.5\end{array}$ & $\begin{array}{l}58.2 \\
60.2 \\
58.2 \\
60.4 \\
59.3\end{array}$ & $\begin{array}{l}29.8 \\
30.5 \\
30.7 \\
29.7 \\
29.3\end{array}$ \\
\hline 47 & $\begin{array}{l}\text { normal- } \\
\text { ized }\end{array}$ & longl & $\begin{array}{l}1 \\
2 \\
3 \\
4 \\
5\end{array}$ & $\begin{array}{l}30.0 \\
30.0 \\
28.5 \\
29.1 \\
27.8\end{array}$ & $\begin{array}{l}45.5 \\
45.2 \\
44.3 \\
44.7 \\
43.9\end{array}$ & $\begin{array}{l}66.0 \\
66.4 \\
64.4 \\
65.1 \\
62.0\end{array}$ & $\begin{array}{l}30.8 \\
32.4 \\
31.5 \\
33.2 \\
32.0\end{array}$ \\
\hline 47 & $\begin{array}{l}\text { normal. } \\
\text { ized }\end{array}$ & trans & $\begin{array}{l}1 \\
2 \\
3 \\
4 \\
5\end{array}$ & $\begin{array}{l}28.7 \\
30.7 \\
27.9 \\
28.7 \\
29.5\end{array}$ & $\begin{array}{l}44.9 \\
44.7 \\
43.3 \\
44.1 \\
45.5\end{array}$ & $\begin{array}{l}64.0 \\
68.8 \\
63.3 \\
65.1 \\
65.0\end{array}$ & $\begin{array}{l}31.3 \\
31.3 \\
32.8 \\
33.0 \\
31.3\end{array}$ \\
\hline
\end{tabular}

each value shows mean of three specimens 
秋山あり目支たな い。域験片の採取 方向炕上る違いる殆见 どないようである。た だ压延のまっのものと

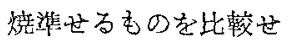
る場合，抗張力以あ末 り変わらないが隆伏点

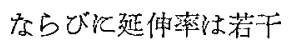
高くなっている。

\section{Vシャルピ 一衝㩓誈験に

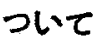

(5.1) Vシャルピー 試娩片採取哭領

武䮶片の採取要制は

Fig. 6 飞宗与如く前項 の引隐試歌の埸合と全 く同様である。ただこ の際表面の住上代を之 るため Rim 部の試駰 片の位堛が $0.5 \mathrm{~mm} た ゙$ け兴部反大っている。

試験片の採取数は・1ン リーズ20ケ宛とし，各 温展ごと江 2 乃至 4 ケ 宛践験を行った。

(5.2) 衝揧試験線果 試駼結果の中，板厚 $40 \mathrm{~mm}$ の場合を Fig. 7 飞，また板厚 $47 \mathrm{~mm}$ の場合を Fig. 8 飞示した。これらに用いた記号中，40,

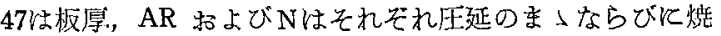
準せるもの，RD，TRANS. はそれぞれ採取方向が正延方 向上これと直角の横方向であること示す. Fig. 7 括よび Fig. 8 上り得られた各遷移百線から, 遷移温度として吸 牧エホルギーが 15ft-lb ならびた $40 \mathrm{ft}-\mathrm{lb}$ となるところ の温度を党らず，をれそれ Tr 15，Tr 40 としてとれらを 測定した. Tr 15 をuctility 遷移温度とすると，後者

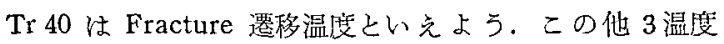

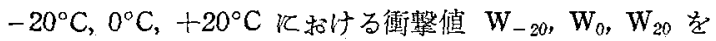
測定し, Tr 15, Tr 40 と共飞Table 3 Kまとた. Fig. 9 は Table 3の綪果より压延方向の採取したむの」 Tr 15 就 よび Tr 40 を，末た Fig. 10 は圧延方向ならびにこれを

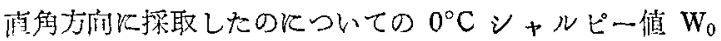

Table 3 Result of V-Charpy Impact Test

\begin{tabular}{|c|c|c|c|c|c|c|c|c|}
\hline $\begin{array}{c}\text { Plate } \\
\text { thickness } \\
(\mathrm{mm})\end{array}$ & Conditinon & Direction & Position & $\begin{array}{l}\mathrm{t}_{r 15} \\
\left({ }^{\circ} \mathrm{C}\right)\end{array}$ & $\begin{array}{l}t_{r 40} \\
\left({ }^{\circ} \mathrm{C}\right)\end{array}$ & $\mid \begin{array}{c}\mathrm{w}-20 \\
\left(\mathrm{~kg}-\mathrm{m} / \mathrm{cm}^{2}\right)\end{array}$ & $\begin{array}{c}\mathrm{w}_{0} \\
\left(\mathrm{~kg}-\mathrm{m} / \mathrm{cm}^{2}\right)\end{array}$ & $\left(\mathrm{kg}-\mathrm{m} / \mathrm{cm}^{2}\right)$ \\
\hline 40 & ar & rd & $\begin{array}{l}1 \\
2 \\
3 \\
4 \\
5\end{array}$ & $\begin{array}{l}-34 \\
-33 \\
-32 \\
-30 \\
-33\end{array}$ & $\begin{array}{l}8 \\
1 \\
0 \\
4 \\
5\end{array}$ & $\begin{array}{l}4.1 \\
4.3 \\
4.4 \\
3.7 \\
4.3\end{array}$ & $\begin{array}{l}5.6 \\
6.6 \\
6.9 \\
6.0 \\
6.0\end{array}$ & $\begin{array}{r}8.3 \\
11.7 \\
12.7 \\
10.9 \\
12.1\end{array}$ \\
\hline 40 & ar & trans & $\begin{array}{l}1 \\
2 \\
3 \\
4 \\
5\end{array}$ & $\begin{array}{l}-24 \\
-30 \\
-30 \\
-30 \\
-25\end{array}$ & $\begin{array}{r}24 \\
13 \\
12 \\
9 \\
29\end{array}$ & $\begin{array}{l}2.8 \\
3.9 \\
2.8 \\
3.4 \\
2.8\end{array}$ & $\begin{array}{l}4.3 \\
6.4 \\
5.4 \\
5.3 \\
4.1\end{array}$ & $\begin{array}{l}6.3 \\
7.8 \\
8.5 \\
8.1 \\
6.1\end{array}$ \\
\hline 40 & $\mathrm{n}$ & $\mathrm{rd}$ & $\begin{array}{l}1 \\
2 \\
3 \\
1 \\
5\end{array}$. & $\begin{array}{l}-33 \\
-30 \\
-31 \\
-28 \\
-26\end{array}$ & $\begin{array}{l}-9 \\
-3 \\
-7 \\
-12 \\
0\end{array}$ & $\begin{array}{l}4.6 \\
3.5 \\
4.7 \\
4.8 \\
4.9\end{array}$ & $\begin{array}{r}9.6 \\
7.6 \\
10.1 \\
9.2 \\
7.6\end{array}$ & $\begin{array}{l}12.7 \\
13.1 \\
14.8 \\
14.5 \\
11.4\end{array}$ \\
\hline 40 & $n$ & trans & $\begin{array}{l}1 \\
2 \\
3 \\
4 \\
5\end{array}$ & $\begin{array}{l}-22 \\
-26 \\
-24 \\
-25 \\
-20\end{array}$ & $\begin{array}{r}16 \\
2 \\
4 \\
13 \\
18\end{array}$ & $\begin{array}{l}2.9 \\
3.8 \\
3.1 \\
3.1 \\
2.6\end{array}$ & $\begin{array}{l}5.0 \\
6.7 \\
6.0 \\
5.2 \\
4.7\end{array}$ & $\begin{array}{l}7.8 \\
8.4 \\
9.1 \\
8.0 \\
7.5\end{array}$ \\
\hline 47 & ar & rd & $\begin{array}{l}1 \\
2 \\
3 \\
4 \\
5\end{array}$ & $\begin{array}{l}-25 \\
-30 \\
-15 \\
-23 \\
-28\end{array}$ & $\begin{array}{l}13 \\
12 \\
12 \\
28 \\
14\end{array}$ & $\begin{array}{l}2.6 \\
3.1 \\
1.8 \\
2.4 \\
3.8\end{array}$ & $\begin{array}{l}6.4 \\
4.8 \\
4.5 \\
5.3 \\
4.5\end{array}$ & $\begin{array}{l}8.1 \\
8.3 \\
8.6 \\
5.0 \\
8.5\end{array}$ \\
\hline 47 & ar & trans & $\begin{array}{r}1 \\
2 \\
3 \\
. \quad 4 \\
5\end{array}$ & $\begin{array}{l}-23 \\
-18 \\
-14 \\
-19 \\
-26\end{array}$ & $\begin{array}{l}38 \\
34 \\
31 \\
34 \\
34\end{array}$ & $\begin{array}{l}2.5 \\
1.8 \\
1.7 \\
2.0 \\
2.2\end{array}$ & $\begin{array}{l}3.7 \\
5.3 \\
3.3 \\
4.3 \\
3.2\end{array}$ & $\begin{array}{l}4.5 \\
4.3 \\
5.4 \\
5.8 \\
5.1\end{array}$ \\
\hline 47 & $\mathbf{n}$ & rd & $\begin{array}{l}1 \\
2 \\
3 \\
4 \\
5\end{array}$ & $\begin{array}{l}-26 \\
-28 \\
-22 \\
-26 \\
-23\end{array}$ & $\begin{array}{l}-4 \\
-2 \\
-4 \\
-1 \\
9\end{array}$ & $\begin{array}{l}3.1 \\
4.4 \\
4.1 \\
3.0 \\
2.9\end{array}$ & $\begin{array}{l}7.3 \\
7.7 \\
9.0 \\
7.1 \\
5.7\end{array}$ & $\begin{array}{l}10.9 \\
13.1 \\
11.7 \\
12.5 \\
10.4\end{array}$ \\
\hline 47 & $\mathrm{n}$ & trans & $\begin{array}{l}1 \\
2 \\
3 \\
4 \\
5\end{array}$ & $\begin{array}{l}-20 \\
-23 \\
-20 \\
-22 \\
-18\end{array}$ & $\begin{array}{l}24 \\
13 \\
14 \\
14 \\
28\end{array}$ & $\begin{array}{l}2.2 \\
3.0 \\
2.5 \\
2.7 \\
2.3\end{array}$ & $\begin{array}{l}4.3 \\
4.9 \\
4.8 \\
5.0 \\
3.7\end{array}$ & $\begin{array}{l}6.8 \\
7.9 \\
7.5 \\
8.0 \\
5.9\end{array}$ \\
\hline
\end{tabular}

$r d$ : rolling direction

trans: transvers direction

を棒グラフルしてわかり易く示したすのである。

(5.3) 考察

Fig. 9 (この図西但温側を上に，亮温側を下にとって あるから棒グラフが上にある注ど，その結果は良好であ る. 以下すべて同し）尤ると全体的にいって，根厚 40 $\mathrm{mm}$ の鋼材怡 $47 \mathrm{~mm}$ の場合に比乙その僄移温度が低温側

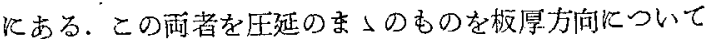

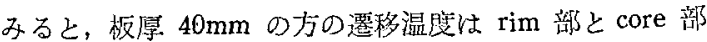

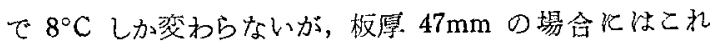
加 $16^{\circ} \mathrm{C}$ となっている. 特旅 core 部 (position (3), (4) K ついていえば，前者の Tr 40 では rim 部ががって焦く 出ているが, 後者の方は core 部に比しいちように高温側 流っている。

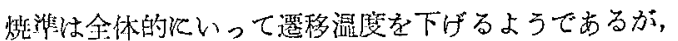




\begin{tabular}{r|c|c|c|c|c}
\hline $\begin{array}{r}\text { Plate } \begin{array}{r}\text { Center } \\
\text { thine }\end{array} \\
\text { lhickness }\end{array}$ & a & b & c & d & e \\
\hline 40 & 5.5 & 12.5 & 20 & 27.7 & 34.5 \\
47 & 5.5 & 14.25 & 23.5 & 32.75 & 41.5 \\
\hline
\end{tabular}
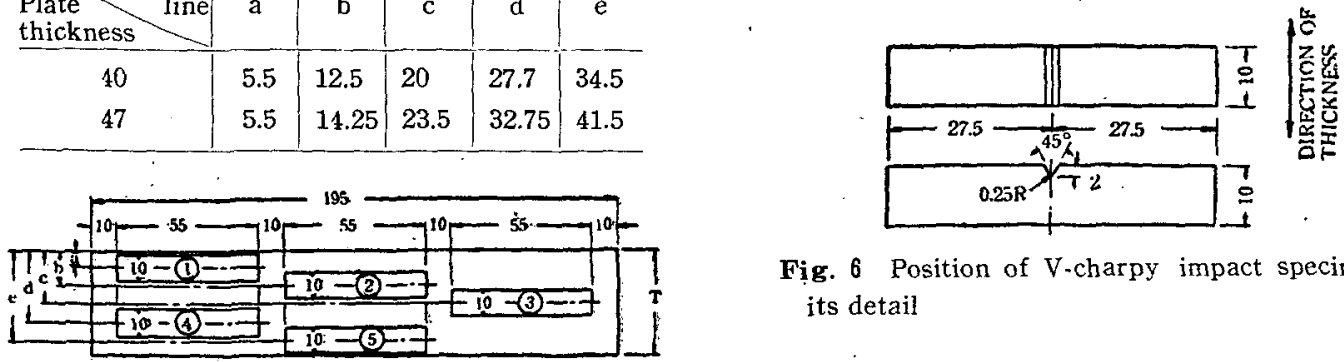

Fig. 6 Position of V-charpy impact specimen and its detail

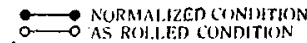
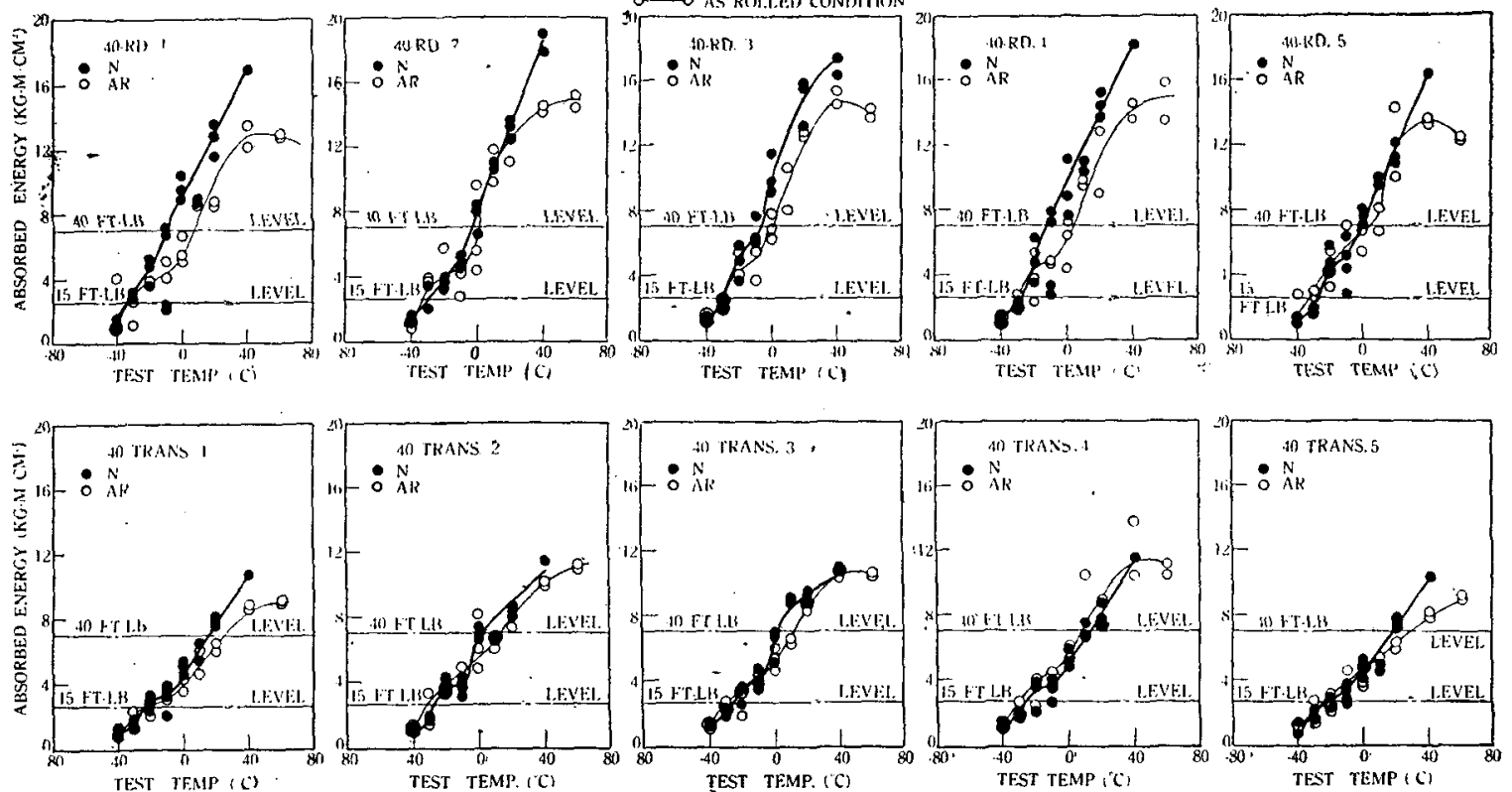

Fig. 7 Result of V-charpy impact test for $40 \mathrm{~mm}$ thick plates
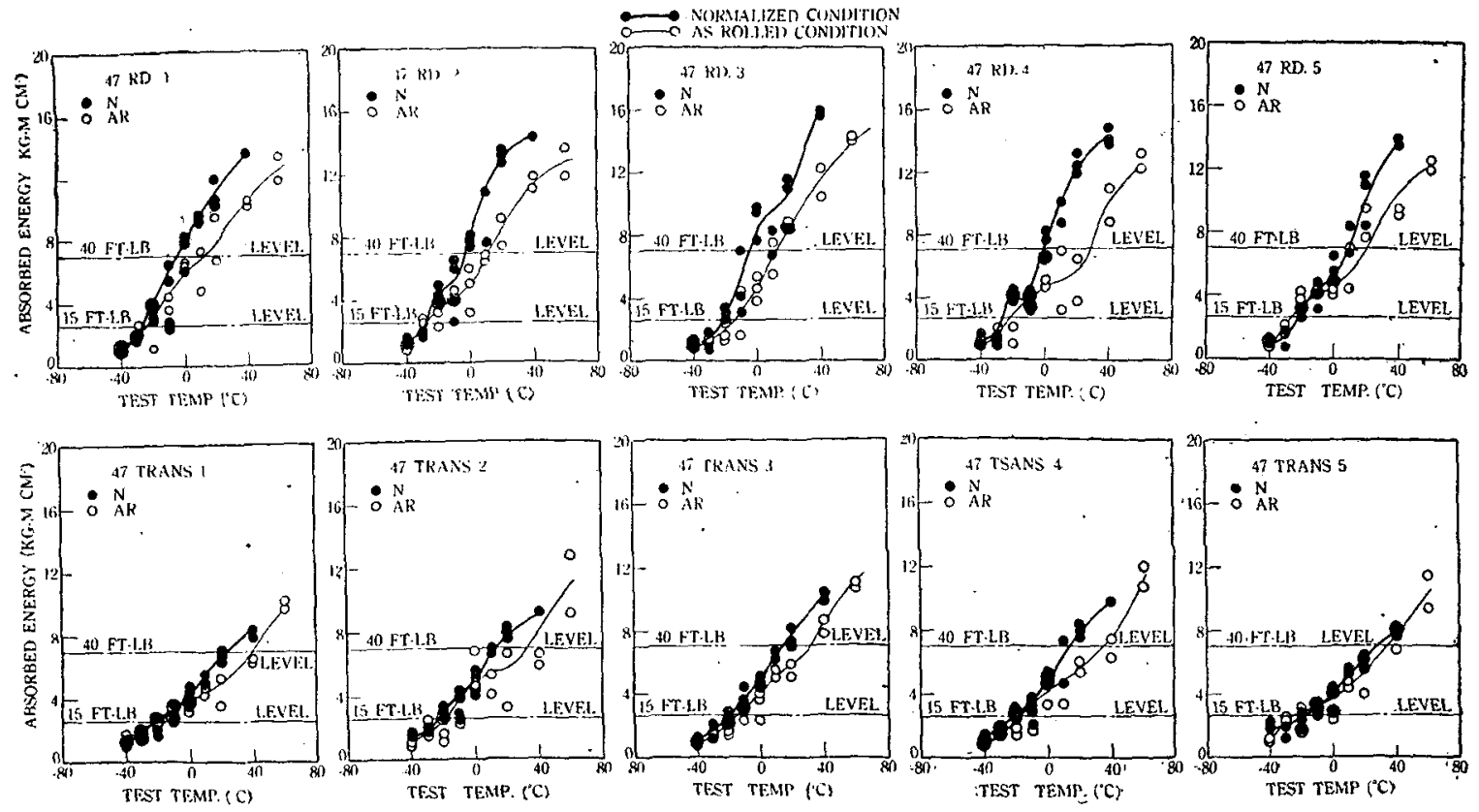

Fig. 8 Result of V-charpy impact test for $47 \mathrm{~mm}$ thick plates 


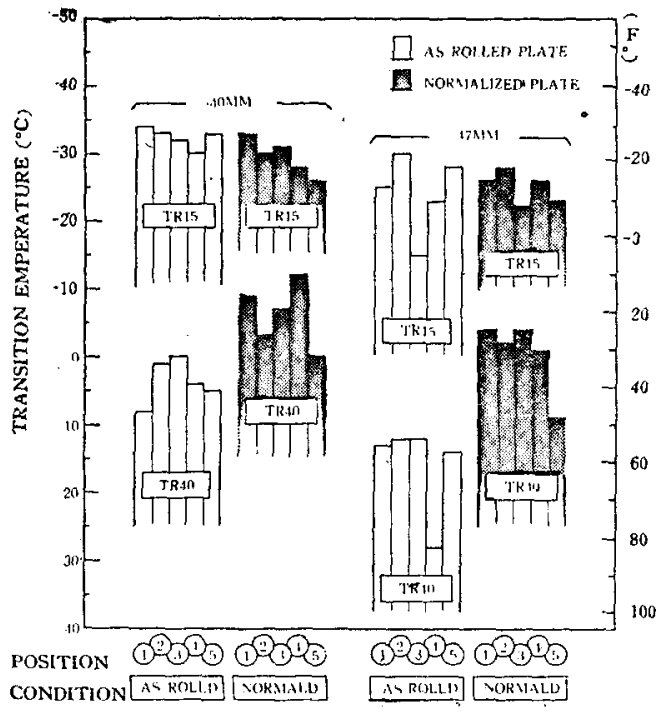

Fig. 9 Summaries of standard V-charpy tests, showing the effects of plate thickness and normalizing

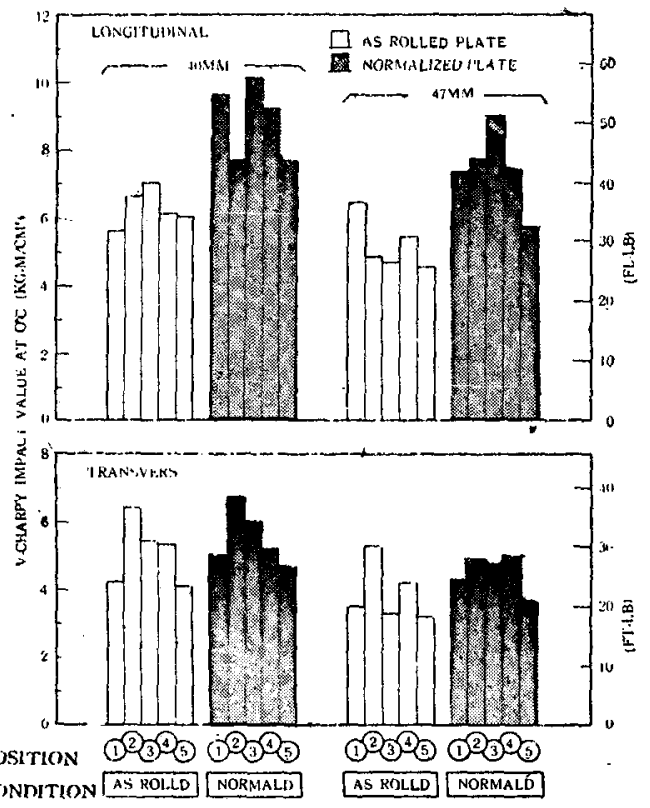

Fig. $10 \mathrm{~V}$-charpy impact value at $0^{\circ} \mathrm{C}$ for as rolled and normalized plates, $40 \mathrm{~mm}$ thick.

この效果は Tr 15 と Tr40 とで大分異なっている。すな

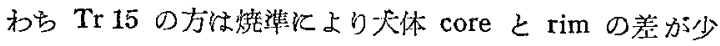
なくなっているもの子全体としてあまり変化がないのに比 し， $\operatorname{Tr} 40$ の方は全体が著しく低温側洺っている $\operatorname{Tr} 15$ は Ductility 遷移温度とされて扔りまたこの場合 Tr 40 は大体1/2エホルギー迷移温度汇近いと考光られるから，以 上よりして，焼淮は Ductility 息移温度にはあまり影仿し

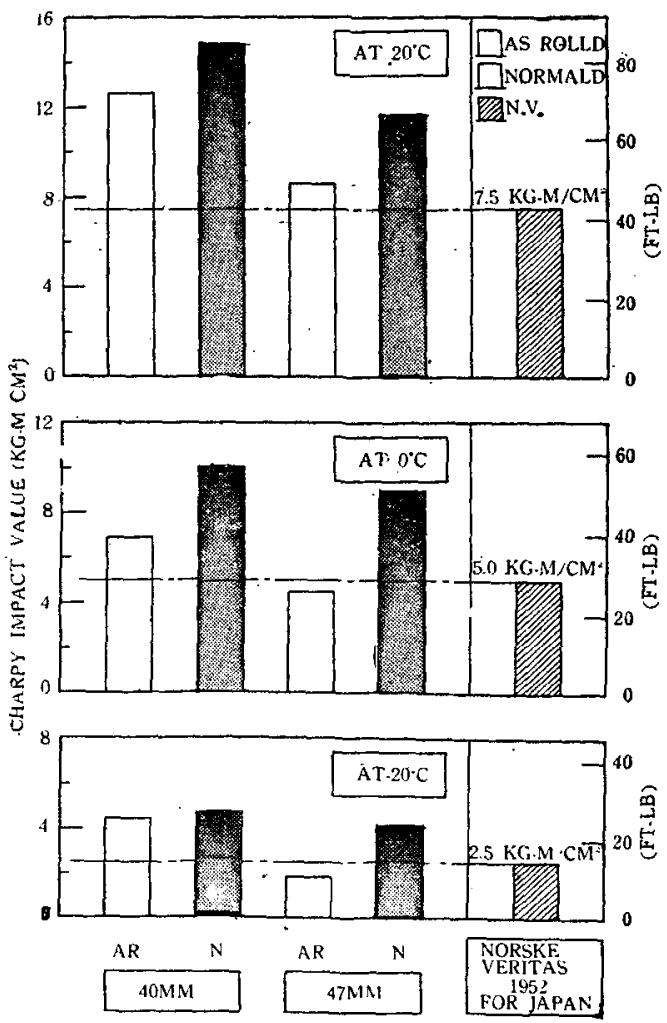

Fig. 11 V-charpy impact value at $20^{\circ} \mathrm{C}, 0^{\circ} \mathrm{C}$ and $20^{\circ} \mathrm{C}$, as compared with those required under det norske veritas rule

ないが Fracture 遷移温度を下げる点で効果があるといえ 上う.

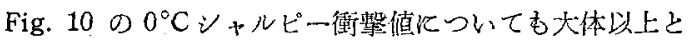
同様のことがいえるようで，やはり板厚 $40 \mathrm{~mm}$ のむのは

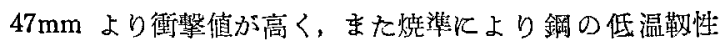

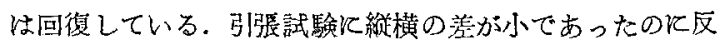
し，この場合は横方向恃若下低く，特に长したものにる いての差が大である。

以上の如く板厚 $47 \mathrm{~mm}$ のもの $40 \mathrm{~mm}$ の場合に比し 切欠醛性の点でや劣っているが，この程度は乞う大差は ないとい光よう、いま做りに切欠鞁性の最低必要なるレべ ルの例を Det Norske Veritas 規程（1952年，日本向け規 格）とよるならな゙，(Fig. 11 参照） $20^{\circ} \mathrm{C}$ 飞招ける衝慗

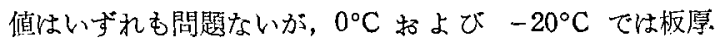
$47 \mathrm{~mm}$ の压延の末」の手のは規格飞少し足らない。

次飞運輸技研ならびK日本海事協会で行われた䒠駼资 料りを基にして以」の $\operatorname{Tr} 15$ ならびに $\mathrm{W}_{0}$ を判断すると 次のようとなる。

すなわち Fig. 12 ならびル Fig. 13 はそれぞれ船体用

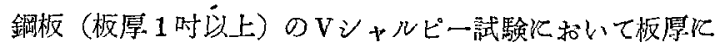
伴う $\operatorname{Tr} 15, \mathrm{~W}_{0}$ の変化を示すものであるが，いまこれを 


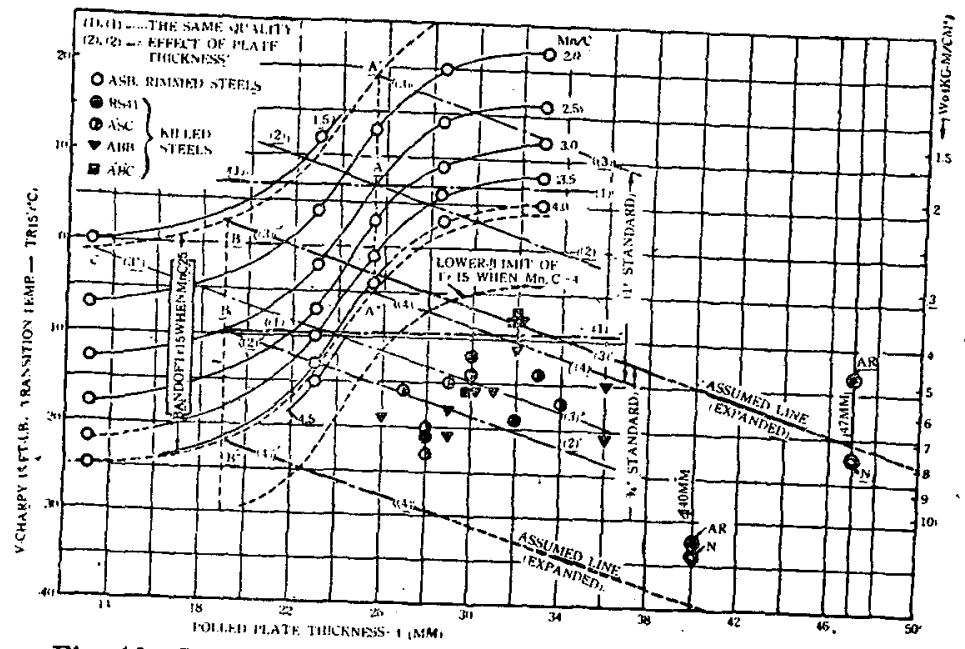

Fig. 12 Comparison of $15 \mathrm{ft}-1 \mathrm{~b}$ transition temperature of both killed and rimmed steels

(from "Notch sensitivity of ship steel plate thicker than one inch"1) by Susuki \& Shibata)
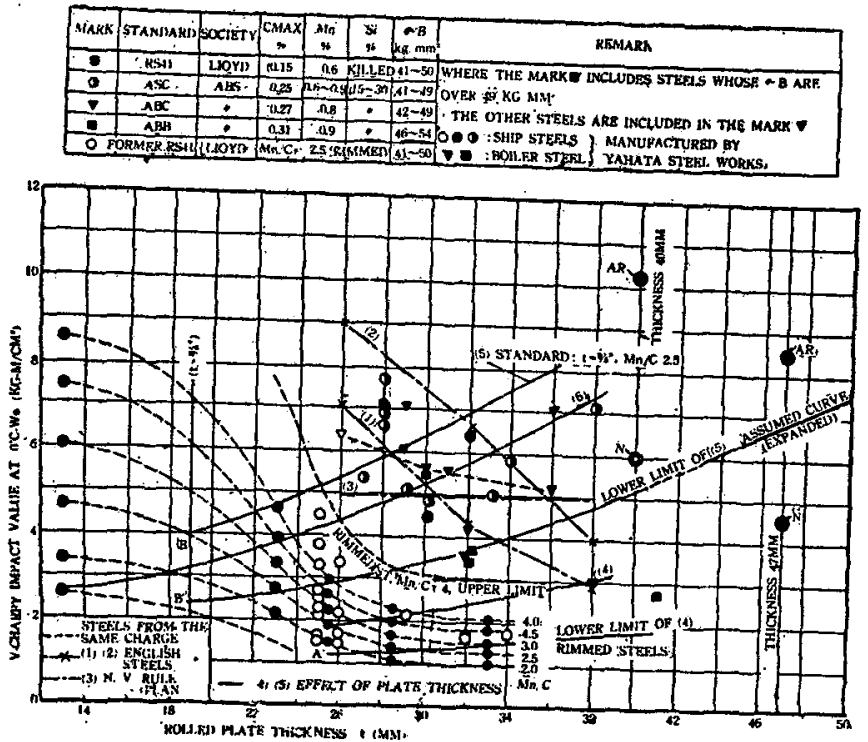

Fig. 13 Comparison of V-chaipy impact value of both. killed and rimmed steels

(from "Notch sensitivity of ship steel plate thicker then one inch"1) by Suzuki \& Shibata)
板厚 $47 \mathrm{~mm}$ まで範囲を㹡げ得るものと して前述の結果を適用してみた、まず Fig. 12 K颃いて $(3)^{\prime}$ ，(4)，の雨直線 飞あればその板は板厚 $3 / 4 ”(19 \mathrm{~mm})$ と同 程度の切久鞄性をむつとされているが， この場合 $47 \mathrm{~mm}$ の压惩のま 外すへてての範囲化入っている。また

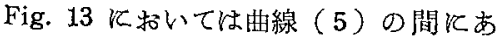
ればやはり同様と考えられているが，こ の場合も同じ結果となっている.

以上を綜合してみると結局压延の大」 の状態では板厚が $40 \mathrm{~mm}$ のものは問題 はないが，47 mm Kなると切久鞀性の 点で思わしくない，しかしこれらを茹準 すればいずれも良好な切欠鞄性をむつと いえよう。

\section{6 縱ビード曲げ試験について}

（6.1）試験片製作要領陚験片ならび に业げ試験治具の方法はすべて1952年の

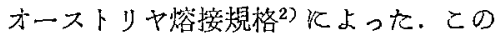
場合の試験片の詳細はに示す。熔接棒は Fig. 4 亿示守如く低水素系 1 種，1ルミ ナイト系 2 種, チタ二ヤ系 1 種含計 4 種 類て，以ずれも神戸製鎦のものを用い た. Table 5 はこれら㗪接棒の熔接条件: を示す、試験材火は板厚 $40 \mathrm{~mm}, 77 \mathrm{~mm}$

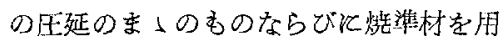
い, 後者については $75^{\circ} \mathrm{C}$ K予熱施工し た場合も行った，Fig. 15 は試験片にビ 一ドを熔接している状况で，手前側の水

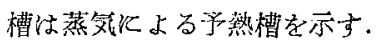

(6.2) 試験絬果

弑験はオーストりや覞格で要求されて いる窒温 $\left(20^{\circ} \mathrm{C}\right.$ 以下) $K$ ，熔接部の低

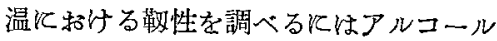
と液体酸素で $-60^{\circ} \mathrm{C}$ 試験温度を 下げて行い，それぞれの試験片の破断特

Table 4 Electrodes Used

\begin{tabular}{|c|c|c|c|c|c|c|c|c|c|c|c|c|c|c|c|c|c|c|c|c|c|}
\hline \multicolumn{2}{|c|}{ Electrode } & \multicolumn{8}{|c|}{$\begin{array}{c}\text { Chemical composition of } \\
\text { core rod }(\%)\end{array}$} & \multicolumn{9}{|c|}{$\begin{array}{l}\text { Chemical composition of } \\
\text { deposit metal }(\%)\end{array}$} & \multicolumn{3}{|c|}{ Mecanical properties } \\
\hline Tipe & JIS & $\mathrm{C}$ & $\mathrm{Mn}$ & $\mathrm{Si}$ & $P$ & $S$ & $\mathrm{Cu}$ & $\mathrm{Ni}$ & $\mathrm{Cr}$ & C & Mn & Si & $\mathbf{P}$ & $S$ & $\mathrm{Cu}$ & $\mathrm{Ni}$ & $\mathrm{Cr}$ & $\mathrm{N}$ & $\begin{array}{c}\mathrm{Y} . \mathrm{P} . \\
\mathrm{kg} / \mathrm{mm}\end{array}$ & $\begin{array}{c}\text { T.S. } \\
\mathrm{kg} / \mathrm{mm}\end{array}$ & {$\left[\begin{array}{c}\mathrm{E} \\
(\%)\end{array}\right.$} \\
\hline LB 26 & 4316 & .09 & .52 & .01 & .008 & .012 & .12 & .04 & .04 & .08 & 1.04 & .43 & .013 & .011 & .10 & .05 & .05 & .012 & 47.2 & 56.2 & 32.7 \\
\hline B 17 & 4301 & .06 & .43 & .01 & .007 & .010 & .09 & .04 & .05 & .09 & .48 & .07 & .028 & .013 & .10 & .04 & .03 & .018 & 44.8 & 50.0 & 26.6 \\
\hline B 10 & 4301 & .06 & .47 & .01 & .008 & .014 & .09 & .04 & .03 & .09 & .38 & .13 & .025 & .014 & .09 & .05 & .03 & .015 & 41.9 & 48 & 26.6 \\
\hline TB24 & $D 4300$ & .07 & .50 & .01 & 011 & .012 & .05 & .04 & .04 & .08 & .37 & .14 & .020 & .014 & .07 & .04 & .04 & .014 & 42.9 & & 28.7 \\
\hline
\end{tabular}




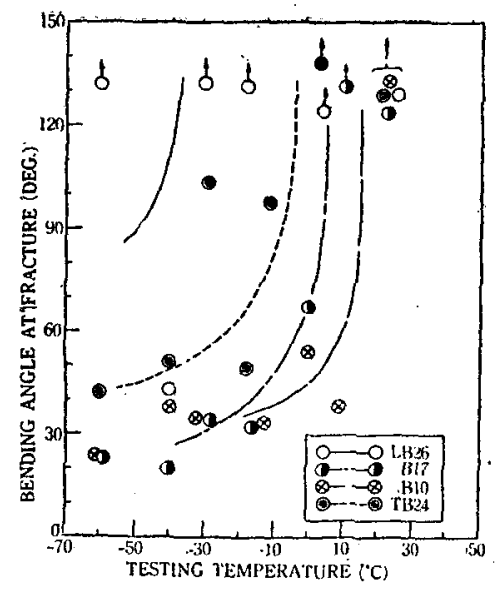

Fig. 16 Trasition curves of kommerell test for $40 \mathrm{~mm}$ thick, as rolled plate

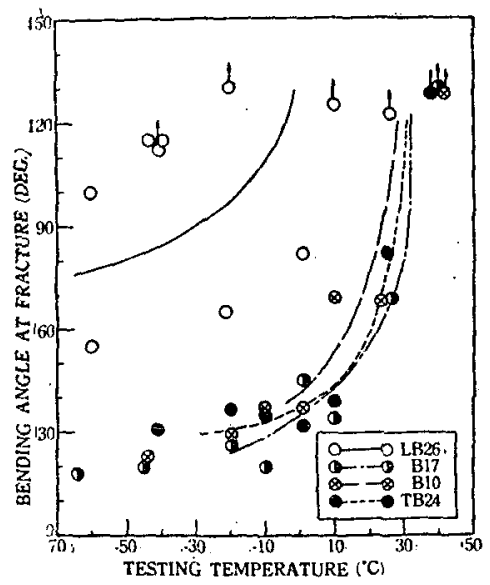

Fig. 13 Transition curves of kommerell test for $47 \mathrm{~mm}$ thick, as rolled plate

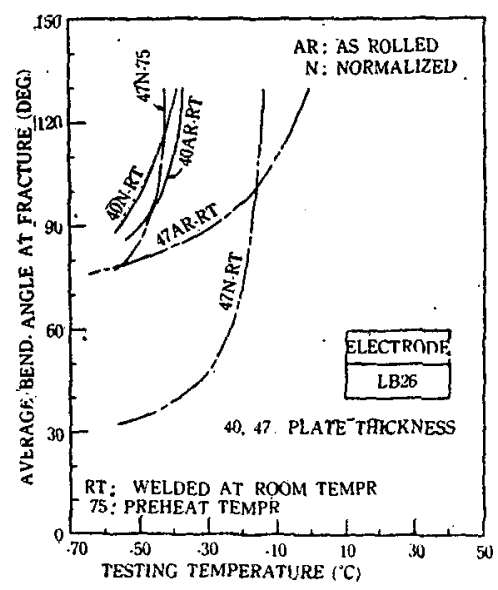

Fig. 22 Transition curves of kommerell test, showing the effect of plate thickness, normalizing and prèheating (Electrode: shinko LB 26, D 4316)

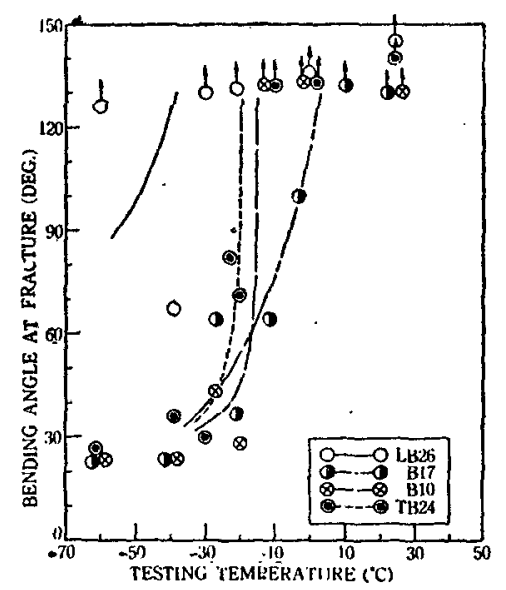

Fig. 17 Transition curves of kom. merell test for $40 \mathrm{~mm}$ thick, normalized plate

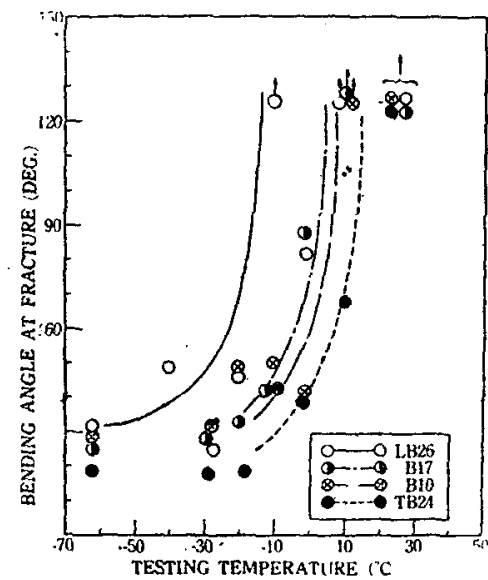

Fig. 20 Transition curves of kommerell test for $47 \mathrm{~mm}$ thick normmalized plate

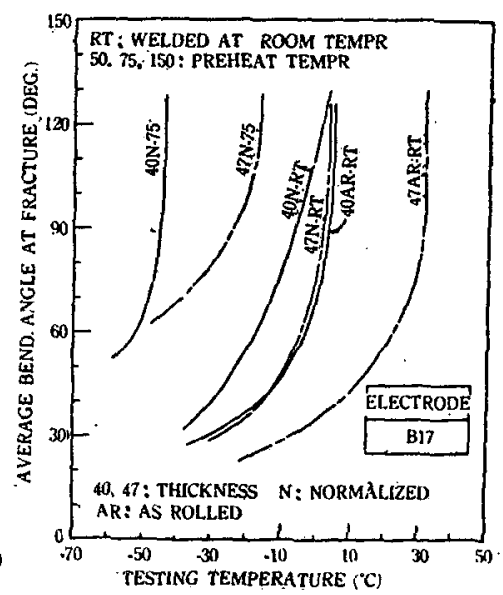

Fig. 23 Transition curves of kommerell test, showing the effects of plate thickness, normalizng and preheating (Electrode: Shinko B 17, D 4301)

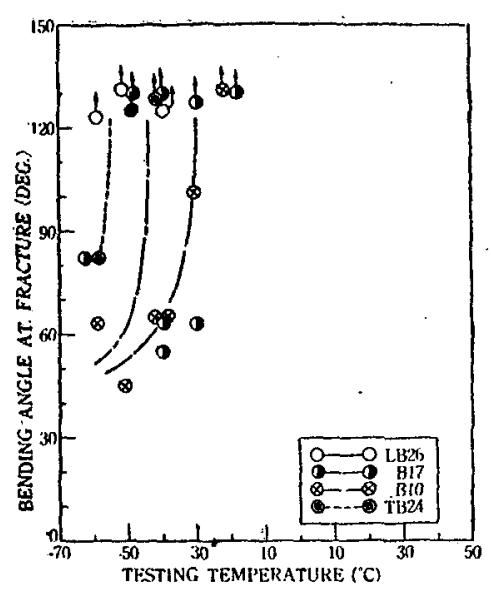

Fig. 18 Transition curves of kommerell test for $40 \mathrm{~mm}$ thick, normalized plate as affect by heating at $75^{\circ} \mathrm{C}$ before welding

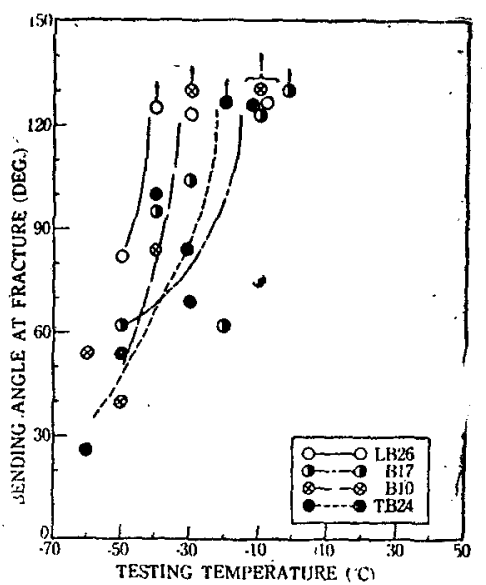

Fig. 21 Transition curves of kommerell test for $47 \mathrm{~mm}$ thick, normalized plate. As affected by heating at $75^{\circ} \mathrm{C}$ before welding

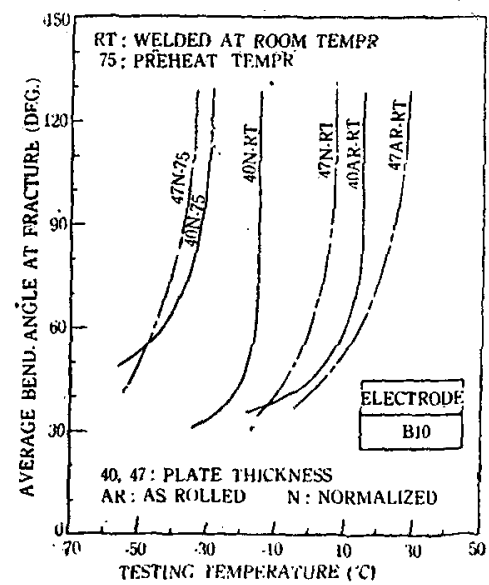

Fig. 24 Transition curves of kommerell test, showing the effect of plate thickness, normalizing and. preheating (Electrode :Shinko B 10, D 4301) 
Table 5 Welding Condition

\begin{tabular}{|c|c|c|c|}
\hline Elect rode & $\begin{array}{l}\text { Weld. } \\
\text { current } \\
\text { (amp) }\end{array}$ & $\begin{array}{c}\text { Arc } \\
\text { voltage } \\
\text { (volt) }\end{array}$ & $\begin{array}{l}\text { Weld. } \\
\text { speed } \\
(\mathrm{mm} / \mathrm{min})\end{array}$ \\
\hline LB 26 & $230 \sim 240$ & 25 & $.145 \sim 165$ \\
\hline B 17. & $235 \sim 240$ & $25 \sim 26$ & $170 \sim 200$ \\
\hline B 10 & $235 \sim 240$ & $25 \sim 26$ & $170 \sim 200$ \\
\hline $\mathrm{Tb} 24$ & $230 \sim 235$ & 25 & $175 \sim 195$ \\
\hline
\end{tabular}
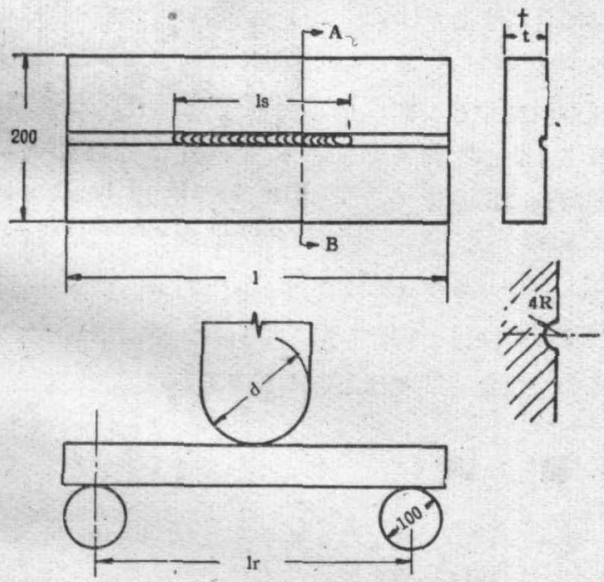

\begin{tabular}{c|c|c|c|c}
\hline $\mathrm{t}$ & $\mathrm{j}$ & $\mathrm{ls}$ & $\mathrm{lr}$ & $\mathrm{d}$ \\
$(\mathrm{mm})$ & $(\mathrm{mm})$ & $(\mathrm{mm})$ & $(\mathrm{mm})$ & $(\mathrm{mm})$ \\
\hline 40 & 470 & 225 & 250 & 135 \\
47 & 500 & 250 & 280 & 150 \\
\hline
\end{tabular}

Fig. 14 Bending jig for kommerell test specimen by Austrian welding standard

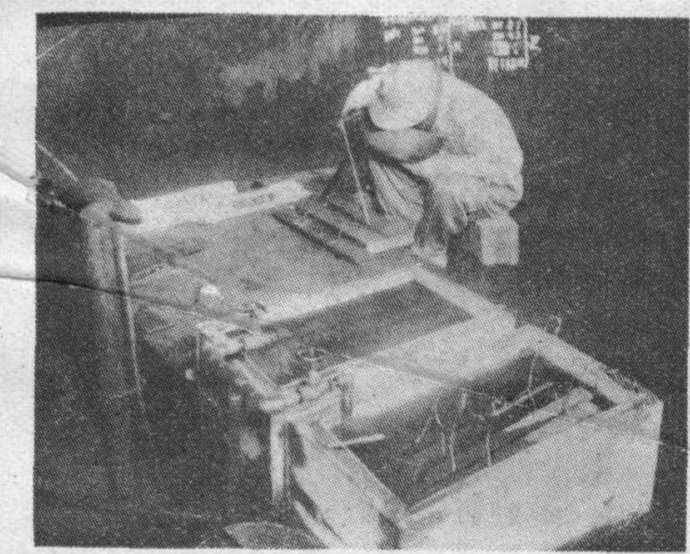

Fig. 15 Welding of kommerell specimens

に示す曲り角度を測定した. これらの試験材別にえられた 結果を Fig. 16〜21 に示す. またこれらの結果をさらに 熔接棒別に示すと Fig. 22〜25 のよらになる.

以上の結果において熔接部の靶性を比較する基準とし て, 便宜上破断時の曲り角度が $90^{\circ}$ となる侍の温度 Tr90 をえらび,これを各くの場合について棒グラフで示したも

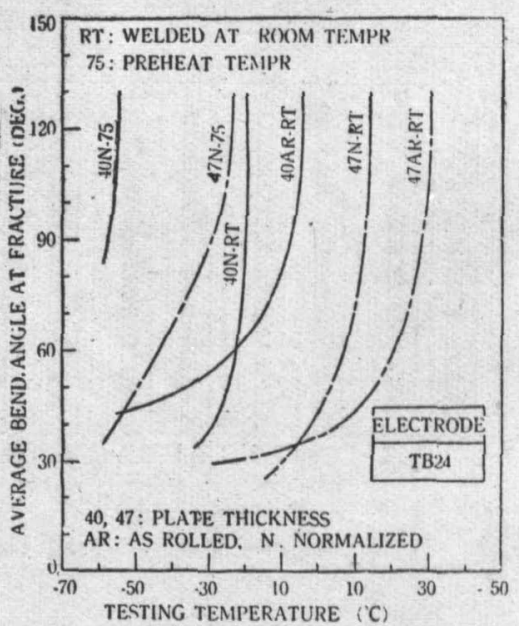

Fig. 25 Transition curves of kommerell test, showing the effects of plate thickness, normalizing and preheating (Electrode: Shinko TB 24, D 4300)

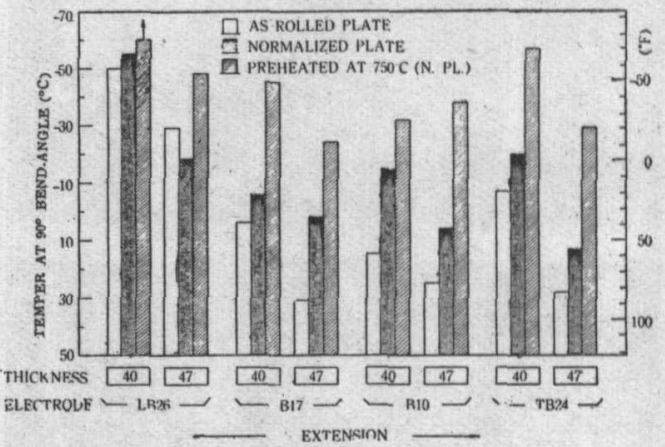

Fig. 26 Summaries of kommerell bend test (1)

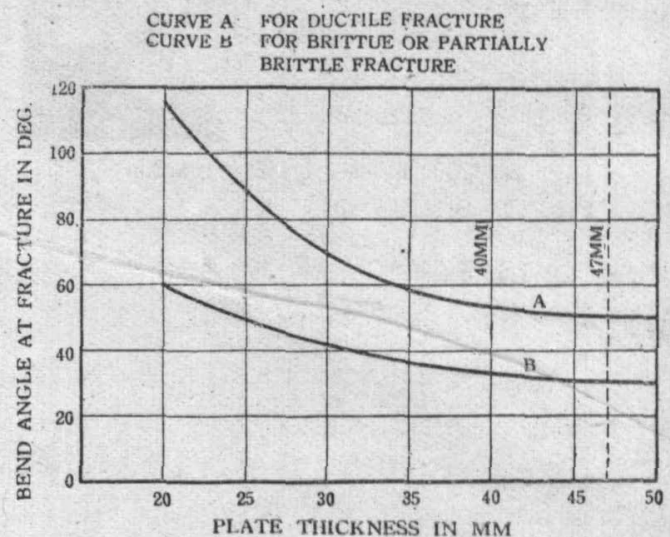

Fig. 27 Bend angles required for plates of defferent thicknesses in the bead bend test under Austrarian welding stanbard. 


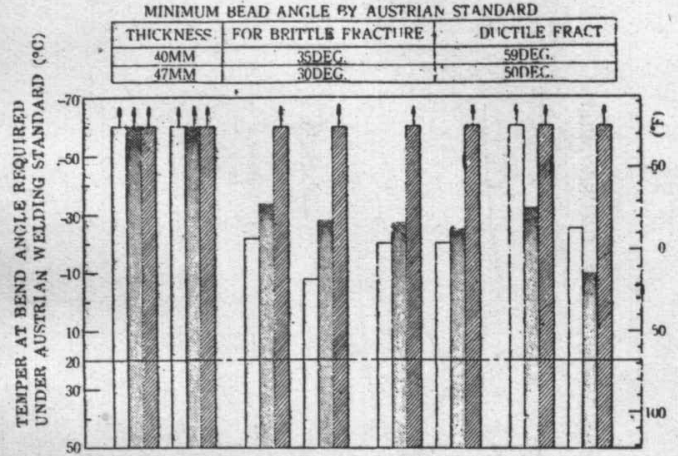

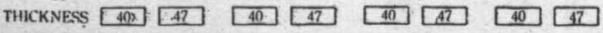

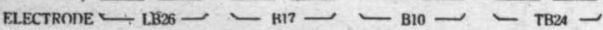
EXTENSION —-

Fig. 28 Summaries of kommerell bead bend test (II)

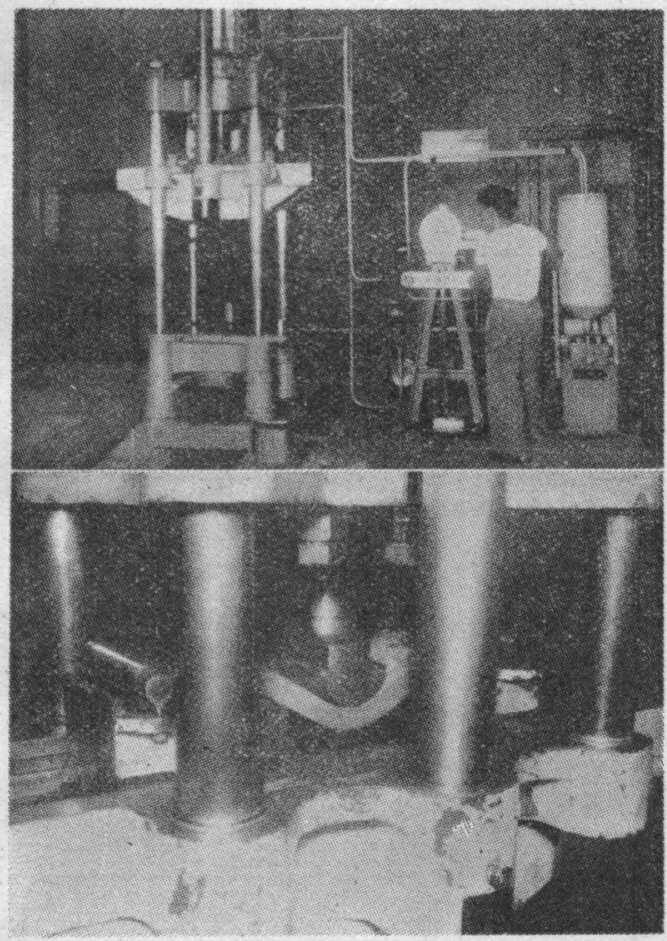

Fig. 29 200t amsler testing machine.

Fig. 30 Bending test

のを Fig. 26 に示す.

\section{(6.3) 考 察}

Fig. 26 飞まとめた結果からみて明らかな如く一般に焼 準すれば試験片の曲り角度は増大している. この傾向は予 熱施工を行った場合さらに大となっている. 板厚 $40 \mathrm{~mm}$ に抬いて $47 \mathrm{~mm}$ の昜合に比して Tr90 は低く来て抲り, また低水素系熔接棒を用いた場合は他の 3 種に比して優れ ているが，他系統の棒でも予熱さえ行えばこれと同等，あ るいはこれ以上の良好な成績を示している。
オーストリヤ規格では縦ビード曲け試験の室温における 曲げ角度を Fig. 27 の如く定めているが，本実験において は被断面はすべて脆性被面であったので四中のB曲線の值 をとると規格で要求せられる曲け角度は板厚 $40 \mathrm{~mm}, 47$ $\mathrm{mm}$ 飞対しそれぞれ $35^{\circ}$ 括よび $30^{\circ}$ となり， 本実験ではいずれすこ れと合格している. い ま規格に合格するだけ の曲り角度が得られる には試験温度をどこま で下げてよいかを調ぺ たのが Fig. 28 の棒グ ラフである.これによ

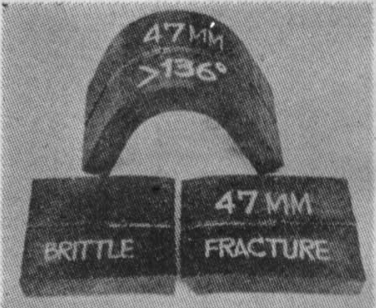

KOMMEAELL SPECIMEN

Fig. 31 Bead bend speciments after testing
るとオーストリヤ規格を問題にする限りではいずれの場合 あ充分すぎるほどの靱性を示して括り，特に予熱施工を行 ったあのでは全く問題はないようである.

\section{7 結 論}

同一チャージの鋼塊より压延せる板厚 $40 \mathrm{~mm}$ と $47 \mathrm{~mm}$ の ABS-C 級鋼材の熔接性を主として使用性能の点から見 て次の如き結論が得られた.

（1）板厚 $40 \mathrm{~mm}, 47 \mathrm{~mm}$ 共飞板厚方向の強度のぼらつ きは $2 \mathrm{~kg} / \mathrm{mm}^{2}$ 以内, 延伸率は $2 \%$ 以内でこの程度なら あまり問題でない.

焼準を行うと降伏点, 延伸率は共に増加しているが, 引 張強度の変化は見られなかった。

（2） Vシャルピー衝撃試験に括いて板厚 $47 \mathrm{~mm}$ の鋼 板は板厚 $40 \mathrm{~mm}$ の場合に比し全般的に切欠感度がや」大 となっている. しかし最も脆化の顕著な core 部に括いて

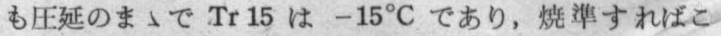
れが $-22^{\circ} \mathrm{C}$ になっている。この温度は少なくも板厚 $11 / 2$ 吋程度までの鋼板の場合についていえば充分低いあのであ るといえる。

(3) 板厚方向の低温勒性のばらつきは板厚 $40 \mathrm{~mm} の$ 場合には問題ないが $47 \mathrm{~mm}$ では相当大である。しかし燒 準によりこのばらつきは除去し得る。

（4）焼準は Tr 40 を大きく下げるが，Tr 15 には特 そ脆化の甚だしい core 部以外あまり影響はないようであ る.このことから低温靭性は鋼材の成分ならびに圧延条件 により大きく決定されるものであるから，これらの焼準以 前の初期の条件が非常に大切であることがわかる.

（5）Det Norske Veritas 規格（1952年日本向）によ りこの結果をみるならば，板厚 $47 \mathrm{~mm}$ の場合には焼準し なければ $\mathrm{W}_{0}, \mathrm{~W}_{-20}$ の点で合格しない，他の研究1)から

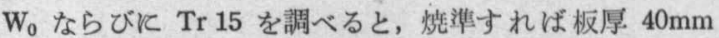


はもらろん $47 \mathrm{~mm}$ の場合でも板厚1/3吋程璒の正延材級材

(ABS-C 級材) と同等の切欠勒性をむつものと荐えられ る.

（6）コンマレル試験に括いては全般に板厚 $47 \mathrm{~mm}$ の むのは $40 \mathrm{~mm}$ K比して曲げ性能が若千少るが，オースト リヤ規格1952年を問題以する限り両者宾住全く問題はない といってよい.

（7）曲げ性能を Tr90Kより判定した場合, 烧倠せ るあのは压延のま」の場合より若干良好々なっている。李 た㐿け性能は燃接棒により異なり，低水素系焀接棒は他の もの比し良好な結果を示している. イルミナイト系と子 タニヤ系ではあまり大差はないが，後筧仙上る結果がや小 優れているようである。

（8）イルミナイト系。また恬チタニヤ系でも試験片の 熔接俰際し予熱を施工すれば低水素系炕少らぬ結果を示し ている。

以上の如く試験材について調查した結果，引张試験，衙 撃武験, 緃ビード湖試験飞関する限り，板厚 $40 \mathrm{~mm} の$ 場合はたと光庄延のまっの状態でも問题はないようであ
る.たよ゙板厚が $47 \mathrm{~mm}$ になると王延のま」の状態では一 部難点屯あるが，烍準を行えば充分これを解决しうるもの 上考克占和る。

\section{追記}

本実験を行うに当り日本製鋼所の皆様に韭常な御尽打を 頂いた．特に谷口課長，小田，蕣野両技師の御援助飞深く 感謝する。

また研究に当っては神戸製鋼所熔接棒部ならびに川崎製 鉄研究部からそれぞれ有益な御助力を頂き，特炕川崎製䜬 今井部長からは笑験以先立らいるいる参考となる御助言を 仰いたことを記し，併せて謝意を㳖する次第である。

\section{考交瀻}

1）熔接船体用厚鋼板（1吋以上）の切欠换性：鈴木保 義・柴田博幸, 通輸技術研究所報告 第 2 巻 第 6 号 p. $27 \sim 53$.

2) New Austrian Welding Standards: Hans Melhardt Welding Journal Vol, 31 (1952) No. 7 p. 592 $\sim 595$.

\title{
突合わせ熔接繼手の橫收縮，橫曲り變形と 熔接條件との關係*
}

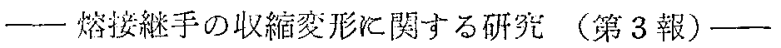

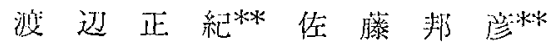

\section{Effect of Welding Conditions on the Transverse Distortion in Butt-Welded Joint}

-Shrinkage Distortion in Welded Joints (Report 3)-

By M. Watanabe** and K. Satoh**

\begin{abstract}
From the results of our previous paper (Report 1), the transverse shrinkage $S_{t}$ in butt-welded joint is given by eq. (3), where $w$ is deposited metal per unit weld length $(\mathrm{gr} / \mathrm{cm}), w_{0}$ is deposited metal per unit weld length per one pass of weld $(\mathrm{gr} / \mathrm{cm}), W$ is total deposited metal per unit weld length $(\mathrm{gr} / \mathrm{cm})$ (see Fig. 1), $h$ is thickness of plate $(\mathrm{cm})$ and $C_{1}$ is a constant. $C_{1}$ is proportional to $(I / \mu a)(1 / \sqrt{\phi})$, where $I$ is welding current (Amp.), $u$ is deposition efficiency of core, $a$ is weight of melted core of electrode per unit current and unit time (gr/A. sec) and $\phi$ is diameter of electrode (mm). Trsnseverse shrinkage of first pass of $S_{t 0}$ is given by eq. (5). I/ $/ \mu a$ depends on the welding conditions and $W / h^{2}$ depends on the grove of butt-joint.

The result of three series of experiments in Table 1 are plotted on the abscissa of log $w$. (see Figs. 2 4). Transverse shrinkage curse is decided by the following two factors:
\end{abstract}

